\title{
Comparison between P\&O and SSO techniques based MPPT algorithm for photovoltaic systems
}

\author{
Mohamed Hussein Mohamedy Ali ${ }^{1}$, Mahmoud Mohammed Sayed Mohamed ${ }^{1}$, \\ Ninet Mohamed Ahmed ${ }^{2}$, Mohamed Bayoumy Abdelkader Zahran ${ }^{3}$ \\ ${ }^{1}$ Electrical Power and Machines Department, Faculty of Engineering, Cairo University, El Giza, Egypt \\ ${ }^{2}$ Photovoltaic Department, Electronics Research Institute, Cairo, Egypt \\ ${ }^{3}$ National Authority for Remote Sensing and Space Science, Cairo, Egypt
}

\begin{tabular}{l} 
Article Info \\
\hline Article history: \\
Received Feb 23, 2021 \\
Revised Jun 8, 2021 \\
Accepted Jul 1, 2021 \\
\hline
\end{tabular}

Keywords:

Maximum power point tracking

Simulink

$\mathrm{P} \& \mathrm{O}$

Photovoltaic system

Salp swarm optimization

\begin{abstract}
Solar photovoltaic (SPV) systems are a renewable source of energy that are environmentally friendly and recyclable nature. When the solar panel is connected directly to the load, the power delivered to the load is not the optimal power. It is therefore important to obtain maximum power from SPV systems for enhancing efficiency. Various maximum power point tracking (MPPT) techniques of SPV systems were proposed. Traditional MPPT techniques are commonly limited to uniform weather conditions. This paper presents a study of MPPT for photovoltaic (PV) systems. The study includes a discussion of different MPPT techniques and performs comparison for the performance of the two MPPT techniques, the P\&O algorithm, and salp swarm optimization (SSO) algorithm. MATLAB simulations are performed under step changes in irradiation. The results of SSO show that the search time of maximum power point (MPP) is significantly decreased and the MPP is obtained in the shortest time with high accuracy and minimum oscillations in the generated power when compared with $\mathrm{P} \& \mathrm{O}$.
\end{abstract}

This is an open access article under the CC BY-SA license.

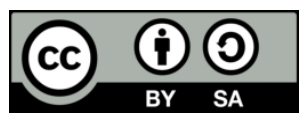

\section{Corresponding Author:}

Mohamed Hussein Mohamedy Ali

Department of Photovoltaic, Electronics Research Institute

El-Bohous St., Previously El-Tahrir St.-Dokki, Giza, Egypt

Email: mohamedali@eri.sci.eg,mohamedyali2020@gmail.com

\section{INTRODUCTION}

There is an expanding requirement to evolve technologies for non-carbon energy sources to fulfill expanding demand of energy without considerable excess of greenhouse gas emissions. The non-sustainable fossil-energy resources won't have the ability to supply energy in the near future. Moreover, the rapid emission increase of greenhouse gases continues to contribute to global warming and subsequently, climate changes. This has compelled researchers and scientists to evolve technologies for substitutional sources of energy that are non-traditional and carbon-free. One of the alternatives for the development of clean energy is solar energy. A photovoltaic (PV) cell which converts direct sunlight into electricity because of the photovoltaic effect brought about by semiconductors is a major contributing technology towards the conquest of global clean and sustainable energy source [1]-[3]. To enhance the utilization of PV arrays, a maximum power point tracker (MPPT) is usually combining with the power converter (DC-DC converter). The essential of utilizing MPPT is to ensure that the PV arrays can always generate the maximum power. However, owing to the change of climate conditions, namely solar irradiation and temperature, the PV characteristic curve discloses a maximum power point (MPP) that varies nonlinearly with these conditions, thus posing a challenge for the tracking algorithm [4]. The main idea of MPPT is to achieve the largest possible power 
from PV arrays with the control of the maximum effective voltage. This implies that MPPT controls the PV array output. MPPT enhances the efficiency of the extracted power output by around $30 \%$ or more when compared to non-MPPT systems [5].

The literature proposes several MPPT algorithms that can be divided into two main categories, conventional and nonconventional algorithms [6]. For traditional methods of MPPT, several techniques have been applied; among them, the most common are incremental conductance (Inc.C), hill climbing (HC), and the most utilized technique is the perturb and observe (P\&O) [7], [8]. HC is relied on perturbing the duty cycle of the linked converter. The Inc.C is measured utilizing the PV system power derivative respecting its voltage, which must have an equivalent value of zero at the MPP; nevertheless, it could have a negative value at the right side of the MPP, and a positive value at the left. The P\&O mostly has a comparable idea to the $\mathrm{HC}$ technique, it is an iterative technique for MPPT; where PV characteristics are measured and then the PV system respective operating point is perturbed in order to meet the change direction.

Biologically inspired methods, which are called also non-traditional methods have gotten more and more attention because of their faster and guaranteed convergence to the MPP. Salp swarm optimization (SSO) algorithm, ant colony systems (ACS), flashing firefly algorithm (FA), particle swarm optimization (PSO), algorism, cuckoo search algorithm (CS) techniques are some of the most common and the latest evolutionary algorithms (EA). The Biologically inspired methods take the benefit of the collective intelligence of identical individuals to increase the operating efficiency and provides the basis of swarm intelligence [9], [10].

In this work, two distinct MPPT techniques are applied for the solar system to take out the maximum obtainable power at the PV, utilizing the MATLAB Simulink tool. Therefore, the main objective point of this work is the comparative evaluation of the simulation results for the salp swarm optimization algorithm as a non-traditional technique, and the $\mathrm{P} \& \mathrm{O}$ method as a traditional technique. The remainder of this paper is arranged as follows. The modeling of the PV module and array based on the work published in [11] is discussed in section two. In Section three, the conventional P\&O method is briefly presented. Section four describes the overview of the SSO and how it is utilized to track the MPP. Section five compares the results gotten using the proposed SSO and P\&O methods. Finally, the conclusion is proposed in the last section.

\section{MODELING OF THE PV ARRAY}

The circuit of the ideal solar cell comprises a source of current that paradigms the sun-based irradiance, a parallel diode paradigm the p-n junction, as presented in Figure 1 [12]. At the point when the sun-powered cells are exposed to sun light, the generated current varies with the sunlight-based irradiance. The resistance connected in parallel and the resistance connected in series is added to the model to represent the losses [13], [14].

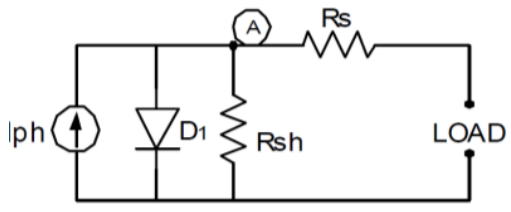

Figure 1. A single diode model solar cell equivalent

The output current of the PV could be gotten from Kirchhoff's law as presented in [15].

$$
\mathrm{I}_{\mathrm{pv}}=\mathrm{I}_{\mathrm{ph}}-\mathrm{I}_{\mathrm{d}}-\mathrm{I}_{\mathrm{sh}}
$$

Where $I_{p v}$ represents the cell current, $I_{p h}$ is the photocurrent, $I_{d}$ is the diode current, $I_{s h}$ is the parallel current.

$$
\mathrm{I}_{\mathrm{d}}=\mathrm{I}_{\mathrm{o}}\left[\mathrm{e}^{\frac{\mathrm{V}+\mathrm{I} \cdot R_{S}}{\mathrm{VT}}}-1\right]
$$

$I_{0}$ is saturation current, $R_{s}$ is serial resistance, $V_{T}$ is the thermal voltage, $q$ is the electron charge $\left(1.6^{*} 10^{-19}\right)$, $\mathrm{T}_{\mathrm{c}}$ is actual cell temperature.

$$
\mathrm{V}_{\mathrm{T}}=\frac{\mathrm{nKT}_{\mathrm{c}}}{\mathrm{q}}
$$




$$
\mathrm{I}_{\mathrm{ph}}=\frac{\mathrm{G}}{G_{r e f}}\left(I_{p h, r e f}+\mu_{s c} \cdot \Delta \mathrm{T}\right)
$$

Where $\mathrm{G}$ is the irradiance, $\mathrm{G}_{\mathrm{ref}}$ is the standard test condition (STC) irradiance $\left(1000 \mathrm{~W} \cdot \mathrm{m}^{-2}\right), \mathrm{I}_{\mathrm{ph}, \mathrm{ref}}$ is the photocurrent at STC, $\mu_{\mathrm{sc}}$ is the coefficient temperature of short circuit current and $\Delta \mathrm{T}\left(\mathrm{T}_{\mathrm{c}}-\mathrm{T}_{\mathrm{c}}\right.$, ref $)$ where the cell temperature at $\mathrm{STC}$ is $\mathrm{T}_{\mathrm{c} \text {, ref. }} \mathrm{I}_{\mathrm{ph}}$ depends on temperature and irradiance.

$$
I_{s h}=\frac{\mathrm{V}+\mathrm{Rs} * \mathrm{I}}{R_{s h}}
$$

Where $R_{\text {sh }}$ is the equivalent circuit shunt resistance. The PV system final equation is measured using (6).

$$
\mathrm{I}_{\mathrm{pv}}=\frac{\mathrm{G}}{G_{r e f}}\left(I_{p h, r e f}+\mu_{s c} \cdot \Delta \mathrm{T}\right)-\mathrm{I}_{\mathrm{o}}\left[\mathrm{e}^{\frac{\mathrm{V}+\mathrm{I} \cdot \mathrm{Rs}}{\mathrm{VT}-1}}\right]-\frac{\mathrm{V}+\mathrm{Rs} * \mathrm{I}}{R_{s h}}
$$

This equivalent circuit given before is for a single cell and therefore an adjustment is required for number of parallel cells $\left(\mathrm{N}_{\mathrm{p}}\right)$ and number of series cells $\left(\mathrm{N}_{\mathrm{s}}\right)$. Therefore, the array current is measured using (7) [11].

$$
\mathrm{I}_{\mathrm{pv}=} N_{p} \mathrm{I}_{\mathrm{ph}}-\mathrm{N}_{\mathrm{p}} \mathrm{I}_{\mathrm{o}}\left[\mathrm{e}^{\frac{q\left(\frac{V d}{N S}+\frac{I R_{S}}{N p}\right)}{n k T c}}-1\right]-\frac{\frac{N p V d}{N S}+I R_{S}}{R_{S h}}
$$

\section{CONVENTIONAL P\&O METHOD}

This is the most generally used method for MPPT. In this algorithm, the controller adjusts the array voltage. These array voltages are initially set with some values. It starts with some threshold value at the first iteration and goes on increasing until the power starts decreasing [16], [17]. If the power increases, then the approach is in the right direction i.e. towards MPP. If power starts decreasing, then the set point is moving away from MPP. Therefore, the voltage value must be decremented. Figure 2 illustrates the flowchart of the P\&O algorithm.

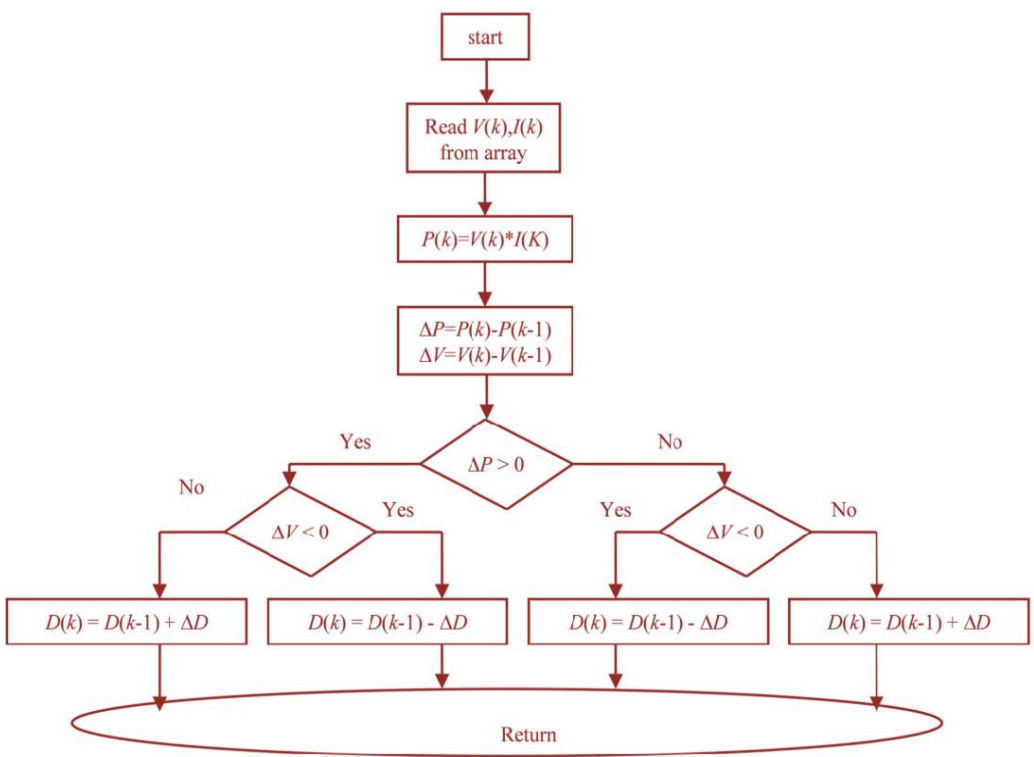

Figure 2. P\&O algorithm flowchart [5]

\section{SSO-BASED MPPT}

Salps are marine organisms. Their shape is like a barrel-shape with a transparent body as displayed in Figure 3. Their movement is done by jet action thrusting of water. They take shape of spiral-like chains, as appeared in Figure 3 for food reconnaissance and better sustainability. SSO is presented firstly in [18] for optimization objectives. Salp chains comprise of a leader and adherents. The leader drives the motion, and 
the adherents upgrade their locations accordingly. The motion of the salp swarm is for investigation and exploitation [19]. Since both are happed in n-dimensional space following the leader, a poise between the adherents and leader is essential for the checking of search space rapidly and exploitation in a localized area for better food consuming. This creates poise between the motion of the leader and its adherents [20], [21].

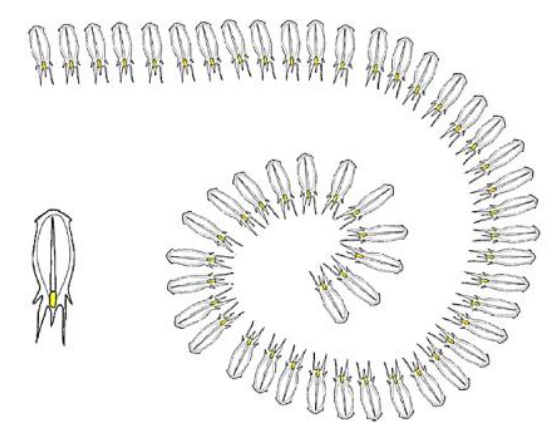

Figure 3. A single salp and a salp chain

The objective of a heuristic algorithm in MPPT is to find MPP with the most limited time in its transient state and reduce the steady-state oscillations around MPP to diminish power loss. SSO is performed for MPPT optimization, considering these two characteristics. The duty cycle is regarded as the search space in our design, which has a range of $[0,1]$. The salp leader location is connected with the output duty cycle. The population is started haphazardly in the search space. Every salp is a probable solution. The nearest salp to the food location is assigned to leadership [22].

\subsection{Mathematical equation for the salp chain}

The model for the salp chain is presented by [23]-[25] and this model is utilized for problem optimization. Two groups of population such as followers and leader are used to represent this model. The forward-facing salp is called a leader, and the other salps in the chain are the followers. The salp position is well defined as $\mathrm{n}$-dimensional search space, and $\mathrm{n}$ represents the variables number. Two-dimensional matrix is used to store the salp position. The swarm goal is supposed to be the source of food in the search space. The position of the leader is updated as in 8 .

$$
X_{j}^{1}=\left\{\begin{array}{l}
F_{i}+C_{1}\left(\left(u b_{i}-I b_{i}\right) c_{2}+l b_{i}\right) C_{3} \geq 0 \\
F_{j}+C_{1}\left(\left(u b_{j}-I b_{j}\right) c_{2}+l b_{j}\right) C_{3}<0
\end{array}\right.
$$

Where the location of leader in the $\mathrm{j}^{\text {th }}$ dimension is named as $\mathrm{X}_{\mathrm{j}}^{1}$, the source of food is denoted as $\mathrm{F}_{\mathrm{j}}$, $u b_{\mathrm{j}}$ and $\mathrm{Ib}_{\mathrm{j}}$ represent the upper and lower bound, respectively, the random numbers are $\mathrm{C}_{1}, \mathrm{C}_{2}$, and $\mathrm{C}_{3}$. From (8), it was seen that the leader location is refreshed imputing to the source of food. The random number, $\mathrm{C}_{1}$ is a significant coefficient in the SSO algorithm, and this coefficient determines the exploitation and exploration. As shown in (9) measures the coefficient, $C_{1}$.

$$
\mathrm{C}_{1}=2 e^{-\left(\frac{4 I}{L}\right) 2}
$$

Where the maximum number of iteration is $\mathrm{L}$, the existing iteration is $\mathrm{I}$. The coefficients $\left(\mathrm{C}_{2}\right.$ and $\left.\mathrm{C}_{3}\right)$ are produced in a random way between $[0,1]$. The adherents location is refreshed as in (10).

$$
X_{j}^{I}=\frac{1}{2} \mathrm{at}^{2}+\mathrm{V}_{\mathrm{o}} \mathrm{t}
$$

Where the adherents location in the $\mathrm{j}^{\text {th }}$ dimension is named as $X_{j}^{I}, \mathrm{i} \geq 2$, the initial quickness is $\mathrm{V}_{\mathrm{o}}, \mathrm{a}=\mathrm{V}_{\text {final }} / \mathrm{V}_{\mathrm{o}}$, and $\mathrm{V}=\mathrm{X}-\mathrm{X}_{\mathrm{o}} / \mathrm{t}$. Assume $\mathrm{V}_{\mathrm{o}}=0$, a time in optimization is denoted as an iteration and inconsistency between the iteration equal to 1. Equation (10) is modified as (11). As shown in (8)-(11) are utilized to model and simulate the salp chains.

$$
X_{j}^{I}=0.5\left(X_{j}^{I}+X_{j}^{I-1}\right)
$$




\subsection{Salp swarm optimization (SSO) algorithm application to MPPT}

The main goal of this technique is to locate the MPP. In the chain of salp paradigm, the adherents follow the leader to the source of food [26]. If the MPP substitutes the source of food, the chain of salp transfers to the MPP. The better solution is the MPP, and the chain of salp flows the source of food. The flowchart for the utilized SSO technique is presented in Figure 4. The stages for the utilized SSO technique are listed:

Stage 1: Initialize the location of the salps with space of search somewhere in the range of $35 \%$ and $85 \%$ of duty ratio for the dc-dc converter.

Stage 2: At every salp location, the power output of PV is maximized with the changing of the duty cycle of the converter and obtains the PV power output.

Stage 3: The salp location is changed as follows: The objective function for the given issue is given in (12).

$$
\mathrm{P}\left(d_{n}^{l}\right)>\mathrm{P}\left(d_{n}^{l-1}\right)
$$

Where the power output of the PV is $\mathrm{P}$, the duty cycle is $\mathrm{d}$, I is the iteration number and $\mathrm{n}$ is the chain slaps number. The duty cycle is represented using (13).

$$
\mathrm{D}_{\mathrm{n}}(1+1)=\mathrm{D}_{\mathrm{n}}(\mathrm{L})-\mathrm{C}_{1}
$$

Stage 4: Repeat stages 3 and 4 till the convergence of all salps.

Stage 5: When the technique finds the MPP. Change the salps dependent on the upper and lower limits of the duty cycle.

The flowchart of the utilized MPPT method begins with the estimated MPP by allocating the haphazard location for the numerous salps. This best value finds the fitness, decides the best suitable salp, and the location of the optimum convenient salp is doled out as a source of food. The variable $\mathrm{F}$ is tracked by the multitude of salps. The $C_{1}$ coefficient is refreshed utilizing (9). At each dimension, the location of the salp leader is refreshed as in (8), and the adherent salp location is refreshed as in (10). In the event that the salp location is out of search space, it will return to the limits.

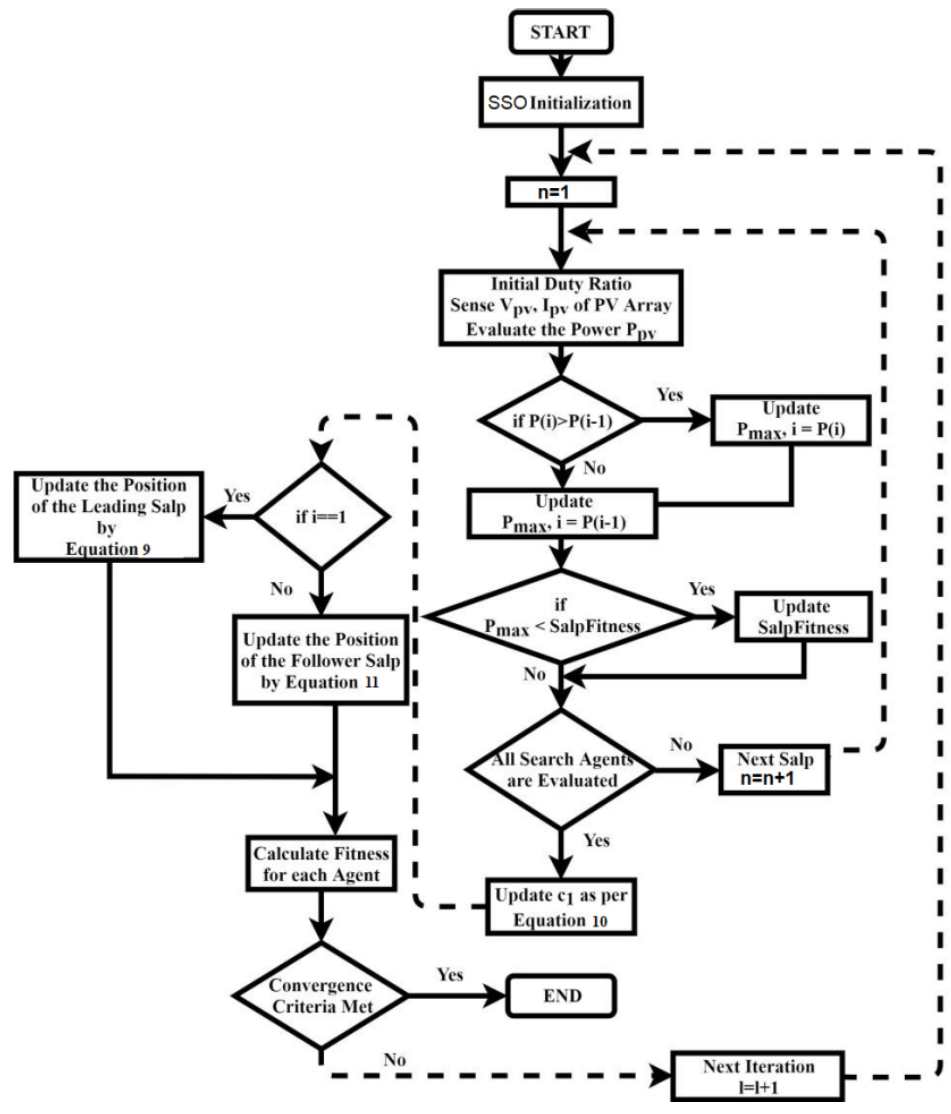

Figure 4. Flowchart of the proposed SSO MPPT 
The stages are reiterated till the convergence norms are met [27]. The source of food is refreshed owing to that salps is probably going to decide the optimal solution by utilizing and investigation around the space of search. The swarm transfers to the MPP. The position of leader salp is the converter duty ratio.

\section{SIMULATION RESULTS}

\subsection{System description}

Significant power parts associated with the off-grid PV system like PV, ESDs, and MPPT were designed utilizing MATLAB/Simulink. The main PV system structure is given in Figure 5. The system was sized by deciding the load demand. Thereafter, the PV modules, battery, and SC sizing were carried out to fulfill the load need [26].

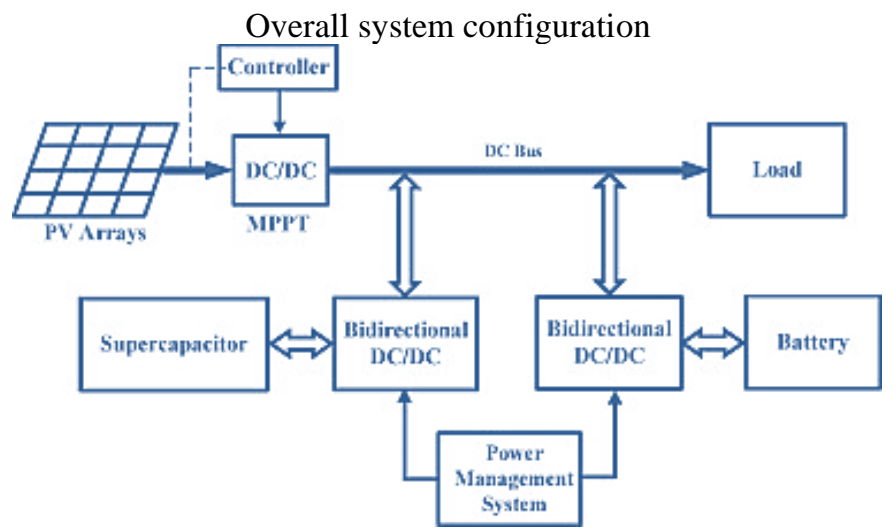

Figure 5. Block diagram of the photovoltaic system with battery-SC energy storage devices

The main parts in the diagram shown before are the PV modules, step up, bi-directional converter, and MPPT. PV modules connected with the step up converter generate a DC power [28]. The power streams into the DC bus are then utilized by the load or stored in a battery and is upheld additionally by SC. bidirectional converters for batteries and SC are utilized to adjust the power provided from (to) SC and batteries depending on the load requirements.

\subsection{Simulation of the proposed PV system}

The design of the system amalgamation as per the attributes of the scheme appeared in Figure 6, which comprises of the model of solar PV and ESDs associated with the DC bus made utilizing the MATLAB/Simulink. To evaluate the effectiveness and compare the two utilized algorithms, P\&O and SSObased MPPT, simulation studies were performed. The duty cycle of the used boost converter is computed using the applied MPPT techniques with Simulink, and the PWM signal is generated. The simulation result for both the traditional method (P\&O) and non-traditional method (SSO) are presented in the next Figure.

The tracking waveforms determined by utilizing SSO and P\&O algorithms are presented in Figure 7. The MPPTs tracking data for irradiation $200 \mathrm{w} / \mathrm{m}^{2}$ are summarized in Table 1 . The suggested PV-Battery-SC system adopts a DC bus construction that is made out of PV modules, batteries, a SC, a step up converter, a Bi-directional converter, and the load. In the suggested system, the DC bus voltage is set $\mathrm{V}_{\text {bus, }}$ and the modules of PV are associated with the DC bus utilizing the step up converter, which attains the PV modules MPPT control.

The results show that the utilized SSO can reach MPP faster than P\&O; Indeed, the oscillations in the photovoltaic power are noticeably identified in the steady state with the P\&O based MPPT compared to the SSO approach, since the duty cycle oscillates around the MPP. The use of the P\&O MPPT technique continuously changes the duty cycle value to allow the MPPT; as a result, the system continues oscillating round this point as shown in Figure 7, which causes power loss in the PV system for increasing running time.

Moreover, at a steady state, the P\&O surrounds the MPPT, nevertheless the SSO still on track for the MPP with the lowest fluctuation as shown in Figure 7. This is show additional benefit for the use of SSO. The oscillation for the SSO technique is regarded as negligible unlike $\mathrm{P} \& \mathrm{O}$ at a steady state that prompts a superior MPPT efficiency. It could be seen that in the first, the SSO consumes a high power because of oscillation as this technique begins with checking for random duty cycle samples. Notwithstanding, this oscillation could be ignored as the particles converge more and more to the MPP. 


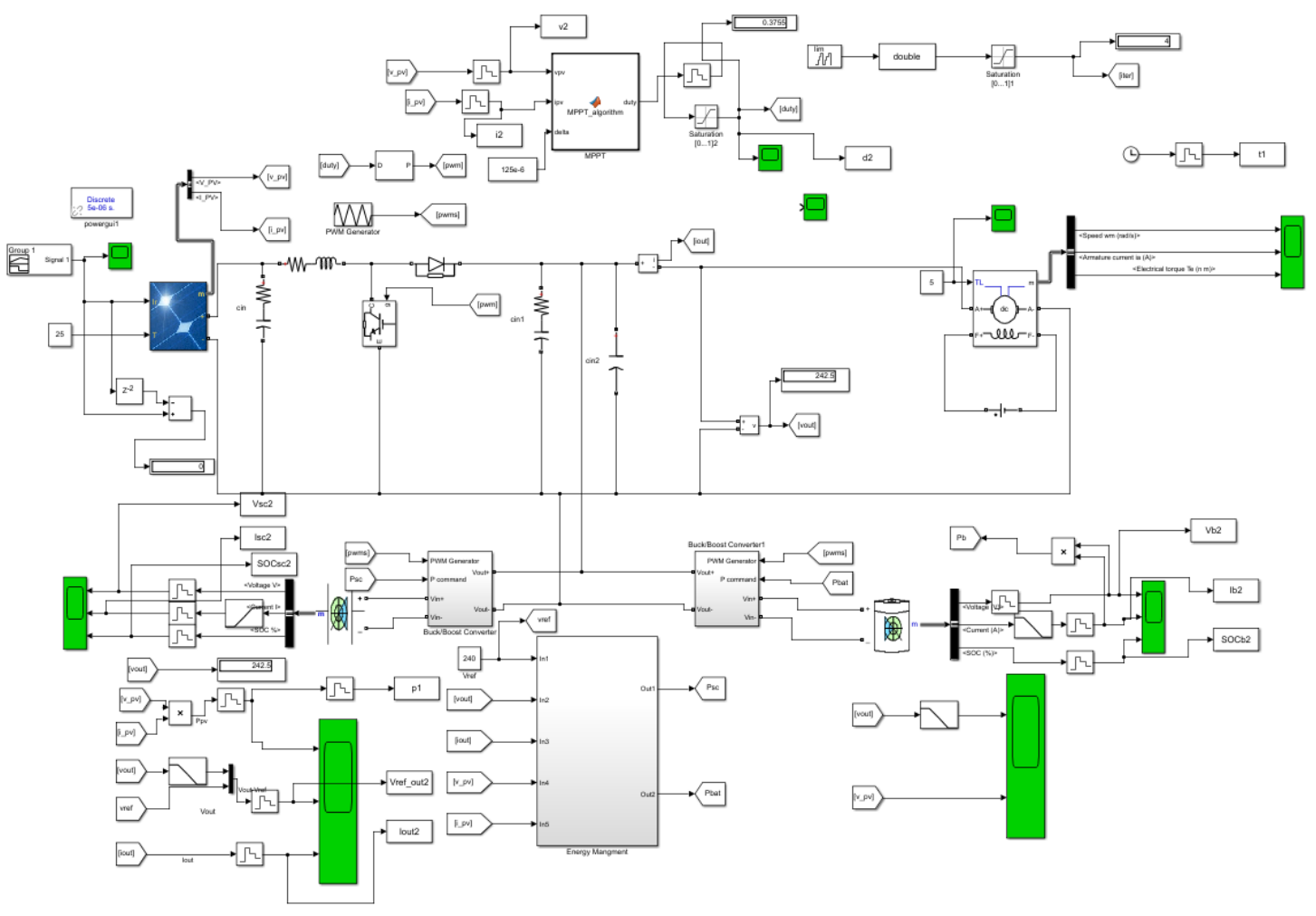

Figure 6. Complete Simulink model of standalone PV battery SC system
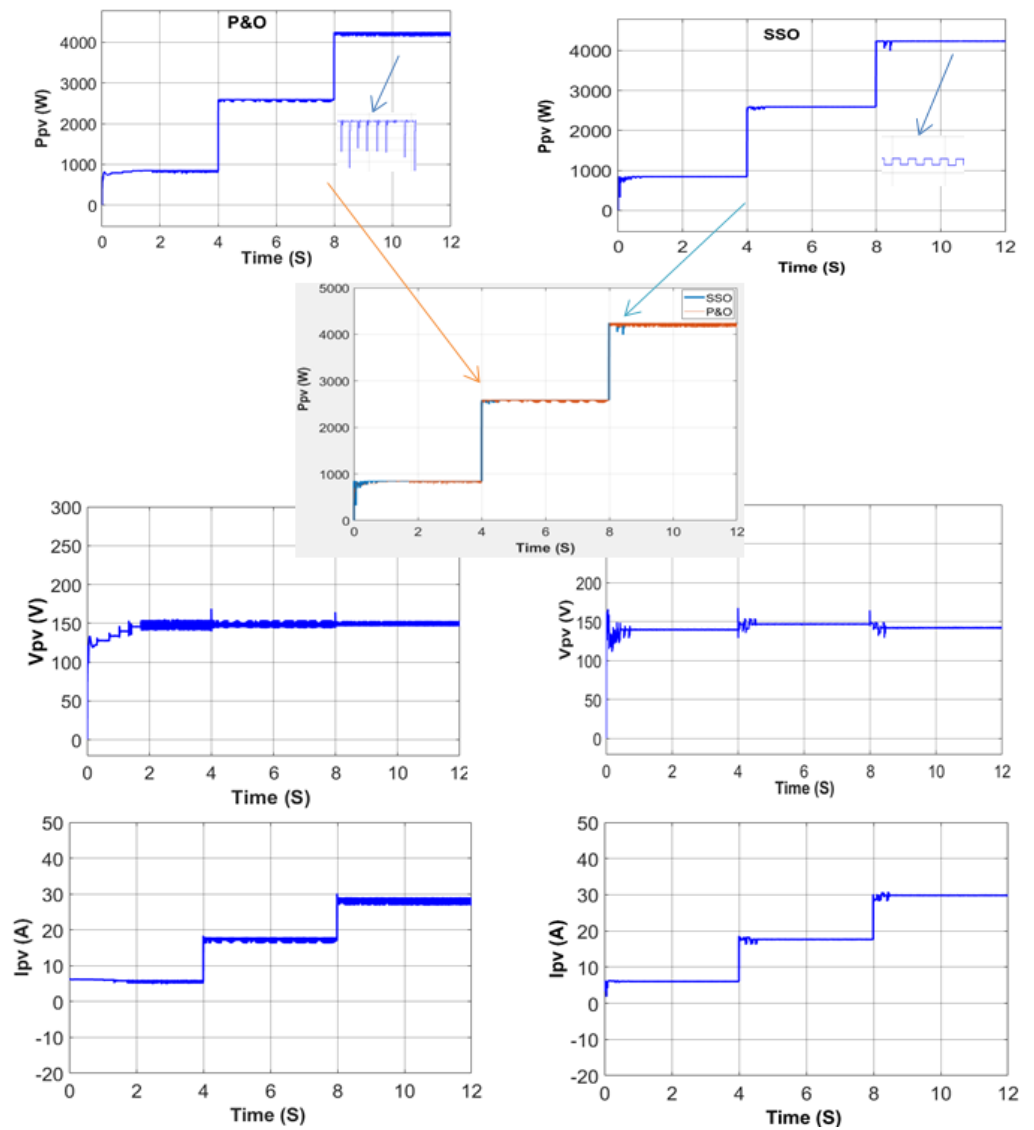

Figure 7. Power, voltage, and current variation of the PV system through MPPT using SSO and P\&O techniques 
Table 1. Performance comparison of $\mathrm{P} \& \mathrm{O}$ and SSO methods

\begin{tabular}{ccccccc}
\hline $\begin{array}{l}\text { Tracking } \\
\text { methods }\end{array}$ & Power (W) & Voltage (V) & Current (A) & $\begin{array}{c}\text { Tracking speed } \\
\text { (seconds) }\end{array}$ & $\begin{array}{c}\text { Maximum power from } \\
\text { P-V curve (watts) }\end{array}$ & $\begin{array}{c}\% \text { Tracking } \\
\text { efficiency }\end{array}$ \\
\hline P\&O & 822.5 & 145.5 & 5.652 & 1.34 & 849.5 & 96.8 \\
SSO & 843.5 & 139.75 & 6.036 & 0.72 & 99.3 \\
\hline
\end{tabular}

\section{CONCLUSION}

This paper presents a simulation comparison between two different MPPT techniques of the PV system applying SSO and P\&O algorithms, in terms of their convergence speed, tracking efficiency, and performance. According to the simulation results, the SSO algorithm was able to reach MPP faster than the $\mathrm{P} \& \mathrm{O}$ technique. Furthermore, it almost shows nearly zero oscillations at a steady state, so this saves much amount of power, regardless of the power loss with the beginning.

\section{REFERENCES}

[1] D. Mills, "Advances in solar thermal electricity technology," Sol. energy, vol. 76, no. 1-3, pp. 19-31, 2004, doi: 10.1016/S0038092X(03)00102-6.

[2] Y.-H. Ji, D.-Y. Jung, J.-G. Kim, J.-H. Kim, T.-W. Lee, and C.-Y. Won, "A real maximum power point tracking method for mismatching compensation in PV array under partially shaded conditions," IEEE Transactions on Power Electronics, vol. 26, no. 4, pp. 1001-1009, 2010, doi: 10.1109/TPEL.2010.2089537.

[3] J. L. Agorreta, M. Borrega, J. López, and L. Marroyo, "Modeling and control of \$ N \$-paralleled grid-connected inverters with LCL filter coupled due to grid impedance in PV plants," IEEE Transactions on Power Electronics, vol. 26, no. 3, pp. 770-785, 2010, doi: 10.1109/TPEL.2010.2095429.

[4] R. A. Cullen, "What is maximum power point tracking (MPPT) and how does it work?," Blue Sky Energy, vol. 16, 2000.

[5] S. M. Sadek, F. H. Fahmy, A. E.-S. A. Nafeh, and M. A. El-Magd, "Fuzzy P \& O maximum power point tracking algorithm for a stand-alone photovoltaic system feeding hybrid loads," Smart Grid and Renewable Energy, vol. 05, no. 2, pp. 19-30, 2014, doi: 10.4236/sgre.2014.52003.

[6] A. N. A. Ali, M. H. Saied, M. Z. Mostafa, and T. M. Abdel-Moneim, "A survey of maximum PPT techniques of PV systems," 2012 IEEE Energytech, 2012, pp. 1-17, doi: 10.1109/EnergyTech.2012.6304652.

[7] M. M. Refaat, Y. Atia, M. M. Sayed, and H. A. A. Fattah, "Maximum power point tracking of photovoltaic system using adaptive fuzzy controller," 2017 Intl Conf on Advanced Control Circuits Systems (ACCS) Systems \& 2017 Intl Conf on New Paradigms in Electronics \& Information Technology (PEIT), 2017, pp. 127-131, doi: 10.1109/ACCS-PEIT.2017.8303030.

[8] M. R. Zekry, M. M. Sayed, and H. K. M. Youssef, "Comparative study of maximum power point tracking methods for photovoltaic system," Journal of Electrical Engineering, vol. 15, no. 4, pp. 289-296, 2015.

[9] V. Phimmasone, Y. Kondo, T. Kamejima, and M. Miyatake, "Evaluation of extracted energy from PV with PSO-based MPPT against various types of solar irradiation changes," 2010 Int. Conf. on Electrical Machines and Systems, 2010, pp. 487-492.

[10] K. Ishaque, Z. Salam, M. Amjad, and S. Mekhilef, “An improved particle swarm optimization (PSO)-based MPPT for PV with reduced steady-state oscillation," IEEE Transactions on Power Electronics, vol. 27, no. 8, pp. 3627-3638, 2012, doi: 10.1109/TPEL.2012.2185713.

[11] A. Harrag and S. Messalti, "IC-based variable step size neuro-fuzzy MPPT improving PV system performances," Energy Procedia, vol. 157, pp. 362-374, 2019, doi: 10.1016/j.egypro.2018.11.201.

[12] Y. Kircicek, A. Aktas, M. Ucar, S. Ozdemir, and E. Ozdemir, "Modeling and analysis of a battery energy storage system supplied from Photovoltaic power source," 7th International Ege Energy Symposium \& Exhibition, 2014, pp. 1-13.

[13] S. Nema, R. K. Nema, and G. Agnihotri, "MATLAB/Simulink based study of photovoltaic cells/modules/array and their experimental verification," International Journal of Energy And Environment (IJEE), vol. 1, no. 3, pp. 487-500, 2010.

[14] F. Z. Amatoul, M. T. Lamchich, and A. Outzourhit, "Design control of DC/AC converter for a grid connected PV systems with maximum power tracking using MATLAB/Simulink," 2011 International Conference on Multimedia Computing and Systems, 2011, pp. 1-6, doi: 10.1109/ICMCS.2011.5945712.

[15] T. T. Marnoto, K. K. Sopian, W. R. Wan Daud, A. M. Algoul, and A. A. Zaharim, "Mathematical model for determining the performance characteristics of multi-crystalline photovoltaic modules," Proceedings of the 9th WSEAS international conference on Mathematical and computational methods in science and engineering, 2007, pp. 79-84.

[16] J. Ahmed and Z. Salam, "An enhanced adaptive P\&O MPPT for fast and efficient tracking under varying environmental conditions," IEEE Transactions on Sustainable Energy, vol. 9, no. 3, pp. 1487-1496, 2018, doi: 10.1109/TSTE.2018.2791968.

[17] A. S. Saidi et al., "A novel approach in stand-alone photovoltaic system using MPPT controllers \& NNE," Ain Shams Engineering Journal, vol. 12, no. 2, pp. 1973-1984, 2021, doi: 10.1016/j.asej.2021.01.006.

[18] S. Mirjalili, A. H. Gandomi, S. Z. Mirjalili, S. Saremi, H. Faris, and S. M. Mirjalili, "Salp swarm algorithm: A bio-inspired optimizer for engineering design problems," Advances in Engineering Software, vol. 114, pp. 163-191, 2017, doi: 10.1016/j.advengsoft.2017.07.002.

[19] M. H. Zafar, N. M. Khan, A. F. Mirza, and M. Mansoor, "Bio-inspired optimization algorithms based maximum power point tracking technique for photovoltaic systems under partial shading and complex partial shading conditions," Journal of Cleaner Production, vol. 309, 2021, Art. no. 127279, doi: 10.1016/j.jclepro.2021.127279.

[20] S. Krishnan and K. Sathiyasekar, "A novel salp swarm optimization MPP tracking algorithm for the solar photovoltaic systems under partial shading conditions," Journal of Circuits, Systems and Computers, vol. 29, no. 01, 2020, Art. no. 2050017, doi: 10.1142/S0218126620500176.

[21] A. F. Mirza, M. Mansoor, Q. Ling, B. Yin, and M. Y. Javed, "A novel salp swarm optimization MPP tracking algorithm for the solar photovoltaic systems under partial shading conditions," Energy Convers. Manag., vol. 209, 2020, Art. no. 112625.

[22] A. F. Mirza, M. Mansoor, Q. Ling, B. Yin, and M. Y. Javed, “A salp-swarm optimization based MPPT technique for harvesting maximum energy from PV systems under partial shading conditions," Energy Conversion and Management, vol. 209, 2020, Art. no. 112625, doi: 10.1016/j.enconman.2020.112625.

[23] V. Andersen and P. Nival, "A model of the population dynamics of salps in coastal waters of the Ligurian Sea," Journal of Plankton Research, vol. 8, no. 6, pp. 1091-1110, 1986, doi: 10.1093/plankt/8.6.1091. 
[24] N. Henschke, J. A. Smith, J. D. Everett, and I. M. Suthers, "Population drivers of a Thalia democratica swarm: insights from population modelling," Journal of Plankton Research, vol. 37, no. 5, pp. 1074-1087, 2015, doi: 10.1093/plankt/fbv024.

[25] A. F. Mirza, M. Mansoor, K. Zhan, and Q. Ling, "High-efficiency swarm intelligent maximum power point tracking control techniques for varying temperature and irradiance," Energy, 2021, Art. no. 120602, doi: 10.1016/j.energy.2021.120602.

[26] O. A. Zongo, "Comparing the performances of MPPT techniques for DC-DC boost converter in a PV system," Walailak Journal of Science And Technology, vol. 18, no. 2, pp. 6500-6515, 2021, doi: 10.48048/wjst.2021.6500.

[27] M. Premkumar, C. Kumar, R. Sowmya, and J. Pradeep, "A novel salp swarm assisted hybrid maximum power point tracking algorithm for the solar photovoltaic power generation systems," Automatika, vol. 62, no. 1, pp. 1-20, 2021, doi: 10.1080/00051144.2020.1834062.

[28] A. Vangari, D. Haribabu, and J. N. Sakamuri, "Modeling and control of DC/DC boost converter using K-factor control for MPPT of solar PV system," 2015 International Conference on Energy Economics and Environment (ICEEE), 2015, pp. 1-6, doi: 10.1109/EnergyEconomics.2015.7235087.

\section{BIOGRAPHIES OF AUTHORS}

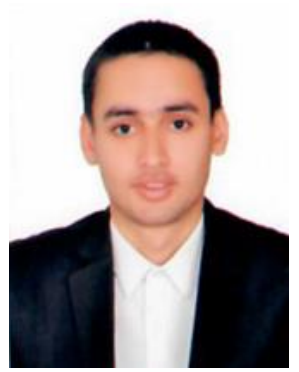

Mohamed Hussein Mohamedy Ali (iD 8) SC P was born in Cairo, Egypt, and received her BSc degree from Ain Shams University, Faculty of Engineering, Electric power and machine Dept. in May 2016. He is currently a Research assistant in Photovoltaic Cells Dept., Electronics Research Institute, since 2017. His experience is mainly in the field of design, control, and optimization of renewable energy systems, supercapacitor fabrication, thin films technologies, and Microcontroller-based applications. He can be contacted at email: mohamedyali@eri.sci.eg; mohamedyali2020@gmail.com.

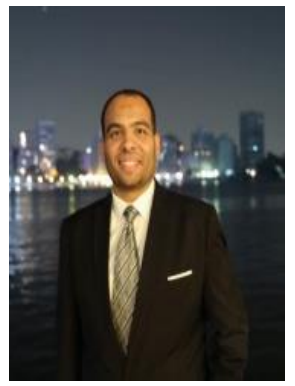

Mahmoud Mohammed Sayed Mohamed (iD) Is SC P was born in Cairo, Egypt, and received his BSc degree from Cairo University, Faculty of Engineering, Electric power and machine Dept. in May 2005, MSc in 2008 from Cairo University, Faculty of Engineering, Electric power and machine Dept. He was awarded her Ph.D. in 2013 from Cairo University, Faculty of Engineering, Electric power and machine Dept. He is currently an associate professor in the Electric power and machine Dept. Faculty of Engineering Cairo University. His experience is mainly in the field of design, control, and optimization of renewable energy systems. He can be contacted at email: Fecu.Msayed@gmail.com.

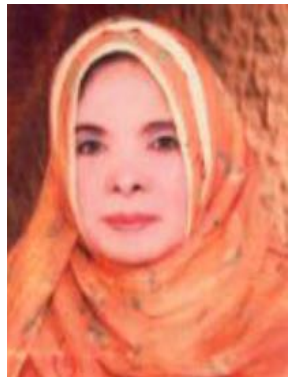

Ninet Mohamed Ahmed (D) SC SC Pas born in Cairo, Egypt, and received her BSc degree from Helwan University, Faculty of Engineering, Communication Dept. in May 1982, MSc in 1997 from Ain Shams University, Faculty of Engineering, Communication Dept. She was awarded her Ph.D. in 2005 from Tanta University, Faculty of Engineering, and Communication Dept. She is currently a professor in Photovoltaic Cells Dept., Electronics Research Institute, since 2018. Her experience is mainly in the field of design, control, and optimization of renewable energy systems, solar cells fabrication, thin films technologies, and Microcontroller-based applications. She can be contacted at email: ninet@eri.sci.eg; ninet321@yahoo.com.

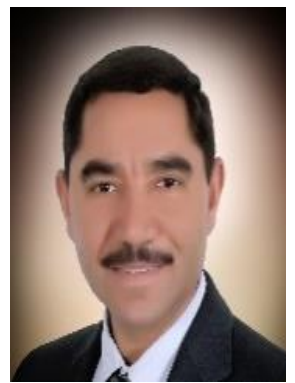

Mohamed Bayoumy Abdelkader Zahran (D) SP SC P was born in Egypt, 1963 received his B.Sc. in 1987 from KHIT with excellent grade, M.Sc. in 1993 from Cairo University, Faculty of Engineering, Electrical Power and Machines Dept., Ph.D. in 1999 from Cairo University, Faculty of Engineering, Electrical Power and Machines Dept. through the scientific channel with Siegen University, funded by DAAD, Germany. He is a Professor Researcher at ERI, Photovoltaic Cells Dept. His experience is mainly in the field of Renewable Energy Sources, Systems Design and Implementation, PVHS Systems Reliability, System Management, and Control. He has been employed full time by the National Authority for Remote Sensing and Space Science (NARSS), Space Division, since 2002 to 2008, power subsystem designer for Egypt Sat 1, System Engineer of MisrSat-2 Project, and Satellite Power Subsystem Designer. He was a Professor, Head of Electrical Engineering Department, Faculty of Engineering, Jazan University, Kingdom of Saudi Arabia, from Oct. 2008 till June 2015. Head of Photovoltaic Cells Dept. Electronics Research Institute, Ministry of Scientific Research and Technology, Egypt, from July 2015 to July 2018. ERI Technical Office Head 2015-2016 Vice President of Electronics Research Institute, Jan. 2017-Feb 2019 Currently, President of the National Authority for Remote Sensing and Space Science. He can be contacted at email: mbazahran@eri.sci.eg; mbazahran_2007@yahoo.com. 